水文・水資源学会誌

\title{
Estimation of the Cumulative Sensible Heat Flux over a Bare Soil and its Daily Mean Soil Temperature without Wind Speed Data
}

\author{
風速データを用いない裸地面での積算顕熱輸送量および日平均地温の推定
}

\author{
Tomoyoshi HIROTA* National Agricultural Center for Hokkaido Region
}

広田知良

(北海道農業研究センター)

\author{
Masato FUKUMOTO** National Institute for Rural Engineering \\ 福本昌人 \\ (農業工学研究所)
}

Ryuichi SHIROOKA***

城岡竜一

Frontier Observational Research System for Global Change

Kazushige YAMADA*

(地球観測フロンティア研究システム)

山田一茂

National Agricultural Center for Hokkaido Region

(北海道農業研究センター)

The exchange speed $\left(C_{H} U\right)$ for sensible heat flux is one of the most important parameters for estimating sensible and latent heat fluxes by the bulk transfer method. $C_{H} U$ is also important for estimating soil temperature by using the heat balance model combined with the bulk transfer method. $C_{H} U$ is usually treated as a function of wind speed; however, if wind speed data is not available, it is not easy to estimate an accurate and representative value using measured wind speed from another location due to the effect of the surrounding environment. In this study, we investigated the accuracy of estimating the sensible heat flux over a bare soil surface and its daily mean soil temperature by the bulk transfer method using daily mean meteorological data without wind speed. This means that $C_{H} U$ is treated as a constant value. We also investigated a method of parameterization of $C_{H} U$ on a bare soil without observed flux data. The estimation of the daily mean sensible heat flux without wind speed data has a large root mean square error (RMSE). RMSE without wind speed was $18.3 \mathrm{~W} \mathrm{~m}^{-2}$. whereas that with wind speed was 10.5 $\mathrm{W} \mathrm{m} \mathrm{m}^{-2}$. However, the accuracy of the estimation of cumulative monthly sensible heat flux without wind speed data was almost equal to that with wind speed data. The two values of RMSE of monthly estimations with and without wind speed data were about $5 \mathrm{~W} \mathrm{~m}^{-2}$. The estimated cumulative sensible heat flux without using wind speed data, over a period of more than several days, agreed with observed sensible heat flux values. With theoretical analysis and the parameterization of $C_{H} U$ on a bare soil without using observed flux data, the results indicate that cumulative sensible heat flux can be estimated from routine meteorological data without wind speed. The daily mean soil temperature was estimated by the method of Hirota et al. (1995) with and without wind speed data. The accuracy of the estimation of the daily mean soil temperature without wind speed data was almost equal to that with wind speed data. The result indicates that even if wind speed data is not used, the model provides a good estimation of the daily mean soil temperature.

Key words : Sensible heat flux, Buk transfer method, Daily mean soil temperature: Exchange speed, Wind speed: Bare soil

顕熱の交換係数はバルク法による顥熱と潜熱の推定にとって重要なバラメータの一つであり，またバルク法と組み合わせた熱収 支法による地温の推定にとっても重要である．顕熱の交換係数は通常，風速の関数として扱われる，しかし，目的の場所における

"National Agricultural Center for Hokkaido Region, Sapporo 062-8555, Japan

北海道農業研究センター T062-8555 札幌市豊平区羊ヶ丘1

**National Institute for Rural Engineering, Tsukuba, Ibaraki 305-8609, Japan

農業工学研究所 テ305-8609 つくば市観音台2-1-2

***JAMSTEC, 2-15 Natsusima, Yokosuka, Kanagawa 237-0061, Japan

地球観測フロンティア研究システム $\quad$ ○237-0061 横須賀市夏島町2-15 海洋科学技術センター 
風速データを用いることができない場合，他の観測地点の風速データから目的の場所の正確で代表的な風速を推定することは，風 速が周辺の影䁹を受けるため容易ではない，そこで，本研究では風速を用いない場合の裸地面の顐熱輸送量および地温の推定精度 について調べた。これは顕熟の交換俰数を一定值として扱うことを意味する。また，顕熱の交換係数をフラックス観測值を用いな いでバラメータ化した場合の推定についても調べた，風速を用いない場合の日平均影熟輸送豆の推定誤差は大きく，風速を用いた

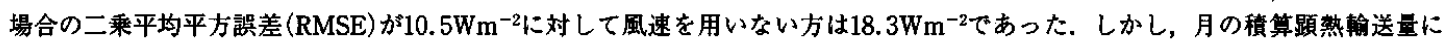
なると風速を用いない場合と用いた場合の両者はほほ同し結果となり，両者の二乗平均平方誤差(RMSE)は共に $5 \mathrm{Wm}^{-2}$ であった。 そして数日から数十日間の風速を用いない積算影熱輸送量の推定値は観測值と自く一致した．理諭的解析とフラックス観湘值を用 いない裸地面での顕熟交換俰数のパラメータの結果を考え合わせると,この結果は裸地面の積算影熱輸送量はルーチン気象観測 データからしかも風速を用いないで推定できるということを示している，日平均地温についても広田ら(1995)の方法を用いて風速 を用いた場合と用いない場合の推定をし，两者の推定精度はほほ同じであることを示したここの結果は，たとえ，風速データを用 いなくてもモデルは日平均地温を精度良く推定できることを示している。

キーワード : 影熱輸送量, バルク法, 日平均地温, 顕熱の交換係数, 風速, 裸地

\section{I . INTRODUCTION}

Sensible heat flux estimated by the bulk transfer method is given by the following equation (e.g. Kondo, 1994).

$$
H=c_{P} \rho C_{H} U\left(T(0, t)-T_{a}\right.
$$

where $H$ is the sensible heat flux $\left(\mathrm{W} \mathrm{m}^{-2}\right), C_{H}$ is the bulk transfer coefficient for sensible heat flux (dimensionless number), $U$ is the wind speed $\left(\mathrm{m} \mathrm{s}^{-1}\right)$, $C_{H} U$ is the exchange speed for the sensible heat flux $\left(\mathrm{m} \mathrm{s}^{-1}\right), C_{H} U$ is also the reciprocal of aerodynamic resistance, $T(0, t)$ is the ground surface temperature $(\mathrm{C}), c_{p}$ is the specific heat of air $(\mathrm{J}$ $\left.\mathrm{kg}^{-1} \mathrm{~K}^{-1}\right), \rho$ is the air density $\left(\mathrm{kg} \mathrm{m}^{-3}\right)$, and $T_{a}$ is the air temperature $\left({ }^{\circ} \mathrm{C}\right)$.

The bulk transfer coefficient $C_{H}$, and the exchange speed $C_{H} U$, are important parameters for estimating sensible heat flux and latent heat flux accurately. These parameters are also important for estimating ground surface temperature and soil temperature by using a heat balance model combined with the bulk transfer method. Soil temperature is an important factor for agricultural managements practice or eco-systems. However, the ground surface temperature or soil temperature is not often observed routinely, even at Japanese routine meteorological station. Accurate ground surface temperature estimation from routine meteorological data is also important for evaluating the sensible heat flux by the bulk transfer method.

$C_{H} U$ is generally treated as a function of wind speed, which is also dependent on the aerodynamic properties of the surface, the scale of fetch and the atmospheric stability (eg., Brutsaert, 1982; Kondo, 1994); therefore it must be determined at each surface station.

With regard to the exchange speed $\left(C_{H} U\right)$ on a bare soil, we obtained almost the same parameterization results between $C_{H} U$ calculated from 30-minute averaged values and $C_{H} U$ calculated from daily mean values (Hirota and Fukumoto, 1996). In addition, we showed that if the soil surface is sufficiently wet, $C_{H} U$ can be estimated by using daily mean values obtained from routine meteorological data without using the observed sensible heat flux.

To evaluate $C_{H} U$ accurately, wind speed $U$ is also important. However, if wind speed data are not available, it is not easy to estimate an accurate and representative value using measured wind speed from another location due to the effect of the surrounding environment. Therefore, it remains a problem to evaluate the sensible heat flux and soil temperature in practice.

On the other hand, Morton (1983) developed an evaporation formula for long-term evaluations in which he suggests the effect of wind speed is eliminated and hence the transfer function can be taken as a constant.

From this viewpoint, it is also important to investigate the accuracy of estimating the sensible heat flux for long-term where only operational meteorological data without wind speed data are 
available.

With this background, the present study investigates the following: the accuracy of estimating the sensible heat flux with the exchange speed $C_{H} U$ treated as a constant value, that is, without using wind speed; and the accuracy of estimating daily mean soil temperature by using a heat balance model with a constant value of exchange speed $C_{H}$ $U$. The effect of varying the time period, from day to seasonal, is also investigated. Then our final purpose is to answer the question,

'Can we estimate the cumulative sensible heat flux from the bare soil by only using routine meteorological data without wind speed ?'

\section{II . THEORETICAL ANALYSIS}

Here, we consider that the calculation of cumulative sensible heat flux both with and without wind speed data, using daily mean values, for periods ranging from one day to seasonal (several month period). They are expressed as follows.

$$
\begin{aligned}
& \Sigma H_{1}=c_{p} \rho \Sigma\left(C_{H} U \Delta T\right) \\
& \Sigma \bar{H}_{1}=c_{p} \rho \overline{C_{H} U} \Sigma \Delta T
\end{aligned}
$$

where, $H_{1}$ is the daily mean sensible heat flux estimated using wind speed, $\bar{H}_{1}$ is the daily mean sensible heat flux estimated without using wind speed, $C_{H} U$ is the exchange speed for daily mean sensible heat flux and it is a function of daily mean wind speed, $\overline{C_{H} U}$ is the mean value of exchange speed $C_{H} U$ and is treated as a constant value, $\Delta T$ is the difference between daily mean ground surface temperature and daily mean air temperature, $c_{p} \rho$ assume the constant value, and the summation $(\Sigma)$ should be taken over the calculation period.

Furthermore, if we divide $C_{H} U$ and $\Delta T$ into the mean component and the fluctuation component during the cumulative period, then $\Sigma H_{1}$ can be expressed as follows:

$$
\begin{aligned}
\Sigma H_{1}= & c_{p} \rho \Sigma\left[\overline{C_{H} U}+\left(C_{H} U\right)^{\prime}\right]\left[\overline{\Delta T}+(\Delta T)^{\prime}\right] \\
= & c_{p} \rho\left\{\Sigma\left(\overline{C_{H} U}\right)(\overline{\Delta T})+\Sigma\left(\overline{C_{H} U}\right)(\Delta T)^{\prime}\right. \\
& \left.+\Sigma\left(C_{H} U\right)^{\prime}(\overline{\Delta T})+\Sigma\left(C_{H} U\right)^{\prime}(\Delta T)^{\prime}\right\} \\
= & n \times c_{p} \rho\left(\overline{C_{H} U}\right)(\overline{\Delta T})+c_{p} \rho\left\{\Sigma\left(\overline{C_{H} U}\right)(\Delta T)^{\prime}\right. \\
& \left.+\Sigma\left(C_{H} U\right)(\overline{\Delta T})+\Sigma\left(C_{H} U\right)(\Delta T)^{\prime}\right\}
\end{aligned}
$$

Here, prime (") denotes the fluctuation component, $n$ is the number of data points, then,

$$
\begin{aligned}
& \Sigma\left(C_{H} U\right)^{\prime}=\Sigma(\Delta T)^{\prime}=0 \\
& \Sigma H_{1}=n \times c_{p} \rho\left(\overline{C_{H} U}\right)(\overline{\Delta T}) \\
& \quad+c_{P} \rho \Sigma\left(C_{H} U\right)^{\prime}(\Delta T)^{\prime}
\end{aligned}
$$

With the similar argument $\Sigma \bar{H}_{1}$ can be expressed as follows:

$$
\sum \bar{H}_{1}=n \times c_{p} \rho\left(\overline{C_{H} U}\right)(\overline{\Delta T})
$$

Hence, the difference between Eq. (2) and Eq. (3) is due to the second term of Eq. (6). If the relationship between $C_{H} U$ and $\Delta T$ is not statistically correlated, Eq (2) agrees with Eq. (3) perfectly. Conversely, if $C_{H} U$ is highly correlated with $\Delta T$ and the standard deviations of $C_{H} U$ and $\Delta T$ are not negligibly small, then the differences between Eq. (2) and Eq. (3) can not be ignored. In order to estimate sensible heat flux without wind speed, we assume that $\Sigma\left(C_{H} U\right)^{\prime}(\Delta T)^{\prime}$ is negligibly small.

This analysis is similar to that presented by others (e.g., Hanawa, 1993) for the estimation of fluxes using the bulk transfer method for sea surfaces.

\section{DATA}

The data from a series of heat budget observations over a bare field (Fukumoto and Hirota, 1994; Fukumoto, 1999) were used to investigate the accuracy of the estimation of the sensible heat flux by the bulk transfer method. These observations were gathered from May 15 to August 14, 1992 over a bare field $(70 \times 40 \mathrm{~m})$ with a volcanic ash soil at the Hokkaido National Agricultural Experiment Station ( $\left.\mathrm{N} 43^{\circ} 0^{\prime} 30^{\prime \prime} \mathrm{E} 141^{\circ} 24^{\prime} 34^{\prime \prime}\right)$. The sensible heat flux over the bare soil field was evaluated using both the Bowen ratio method (day time) and the aerodynamic method (night time). The observation items are shown in Table 1. A more detailed description of the observations is given elsewhere (Fukumoto and Hirota 1994; Fukumoto, 1999). We obtained continuous data except for July 28, July 29 and August 12, 1992 during the observation period. Fig. 1 shows temporal variations of daily mean sensible heat flux and daily mean wind speed from Fukumoto and Hirota (1994) and Fukumoto (1999). In this observation period, the 
Table 1 List of data analyzed in the present study, obtained from Fukumoto and Hirota (1994), Fukumoto (1999).

(1)-(8) were sampled at 1-minute intervals and 30- minutes averaged were recorded. (9) was sampled once a day.

\begin{tabular}{|c|c|c|}
\hline Element & Height or depth (m) & Instrument or calculation method \\
\hline (1) Downward solar radiation $R_{f}$ & 1.7 & Solar radiometer \\
\hline (2) Upward solar radiation (albedo) a & 1.5 & Solar radiometer \\
\hline (3) Net radiation $R_{n}$ & 1.5 & Net radiometer \\
\hline (4) Air temperature $\mathrm{Ta}$ & $0.5,0.05$ & ermocouple in a ventilated shield \\
\hline (5) Water vapor pressure & Thermoco & le psychrometer in a ventilated shiel \\
\hline (6) Wind speed $U$ & $0.5,0.05$ & Three-cup anemometer \\
\hline (7) Ground surface temperature $T(0, t)$ & 1.0 & Infrared thermometer \\
\hline (8) Soil temperatures & $.02,0.05,0.10,0.20,0.35,0.60,1.0$ & Thermocouple \\
\hline (9) Soil moisture & $0-0.02,0-0.05,0-0.1$ & Gravimetric method \\
\hline (10) Soil heat flux & $\begin{array}{r}\text { Combi } \\
\text { plate } \\
\text { soil } \\
\text { (0-0. }\end{array}$ & $\begin{array}{l}\text { ation method using soil heat flux } \\
0.02 \mathrm{~m}), \text { ground surface temperature, } \\
\text { emperature }(0.02 \mathrm{~m}) \text { and soil moisture } \\
\text { (m layer) }\end{array}$ \\
\hline
\end{tabular}

(11) The sensible and

Bowen ratio method and aerodynamic method

latent heat fluxes $H, L E$.

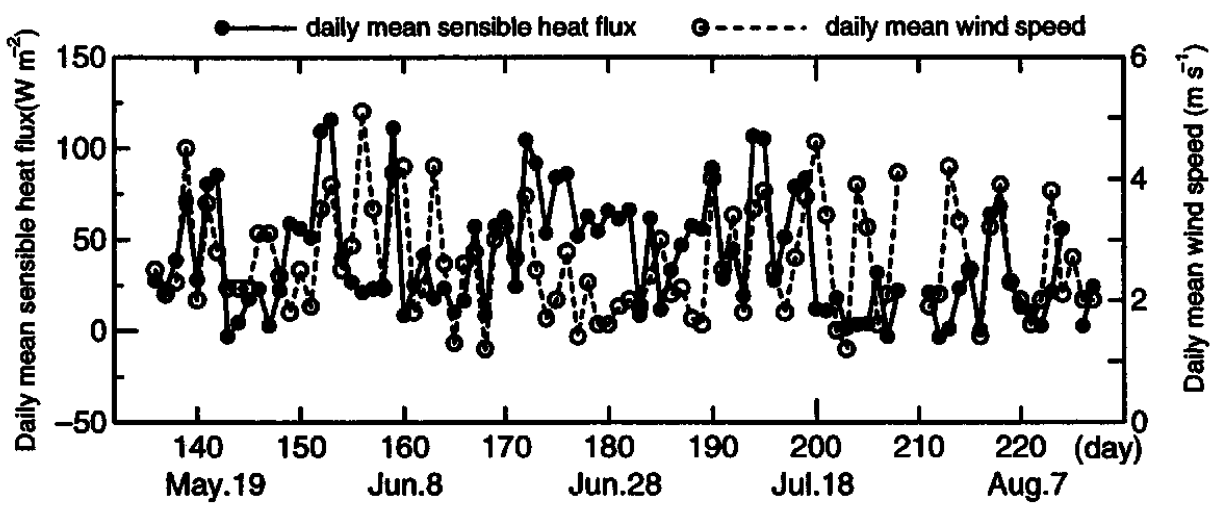

Fig. 1 Temporal variations of daily mean sensible heat flux and daily mean wind speed at a height of 0.5m (The data obtained from Fukumoto and Hirota, 1994 or Fukumoto, 1999)

daily mean sensible heat flux ranged from -3.8 $\mathrm{W} \mathrm{m} \mathrm{m}^{-2}$ to $115.5 \mathrm{~W} \mathrm{~m}^{-2}$ and the daily mean wind speed, at $0.5 \mathrm{~m}$ height, ranged from $1.2 \mathrm{~m} \mathrm{~s}^{-1}$ to $5.1 \mathrm{~m} \mathrm{~s}^{-1}$.

\section{IV . METHOD}

1. Estimation of the sensible heat flux

The daily mean sensible heat flux was estimated by the bulk transfer method, Eq. (1), using daily mean meteorological data. The exchange speed $C_{H} U$ was derived for the following three cases by the method of Hirota and Fukumoto (1996).

CASE 1 Parameterization of $C_{H} U$ using observed sensible heat flux

$C_{H} U$ was calculated using the observed daily mean sensible heat flux as follows:

$$
C_{H} U=\frac{H}{c_{p} \rho\left\{T(0, t)-T_{a}\right\}}
$$

$C_{H} U$ was parameterized using daily mean wind speed $U$ at $0.5 \mathrm{~m}$ height, yielding,

$$
C_{H} U=0.00352 U+0.00067\left(\mathrm{~m} \mathrm{~s}^{-1}\right)
$$


CASE 2 Parameterization of $C_{H} U$ without using observed daily sensible heat flux

If the soil surface is sufficiently wet after plenty of precipitation, the surface moisture availability $\beta$ (see Appendix) can be assumed to be 1. In addition soil heat flux is assumed to be negligible for daily periods. For these conditions, $C_{H} U$ can be calculated without using the observed sensible heat flux as follows:

$$
C_{H} U=\frac{(1-a) R_{\mathrm{s}}+\varepsilon\left\{L_{d}-\sigma(273.15+T(0, t))^{4}\right\}}{c_{p} \rho\left\{T(0, t)-T_{a}\right\}+l \rho\left\{q_{\text {zat }}\{T(0, t)\}-q_{a}\right\}}
$$

where $R_{s}$ is the solar radiation $\left(\mathrm{W} \mathrm{m}^{-2}\right), L_{d}$ is the atmospheric long wave radiation $\left(\mathrm{W} \mathrm{m} \mathrm{m}^{-2}\right), a$ is the albedo of soil surface, $\varepsilon$ is the emissivity of the ground, $\sigma$ is the Stefan-Boltzmann constant (W $\left.\mathrm{m}^{-2} \mathrm{~K}^{-4}\right), l$ is the heat of vaporization $\left(\mathrm{J} \mathrm{kg}^{-1}\right), q_{a}$ is the specific humidity of the air $\left(\mathrm{kg} \mathrm{kg}^{-1}\right)$, and $q_{\mathrm{sar}}(T$ $(0, t))$ is the saturation value of the specific humidity at the ground surface temperature (kg $\left.\mathrm{kg}^{-1}\right)$.

$C_{H} U$ was parameterized using daily mean wind speed $U$ at $0.5 \mathrm{~m}$ in the following equation.

$$
C_{H} U=0.00229 U+0.00456\left(\mathrm{~m} \mathrm{~s}^{-1}\right)
$$

CASE 3 Parameterization $C_{H} U$ without using wind speed data

We treated $C_{H} U$ as a constant and used the average value of CASE 2 in Eq. (10).

$$
C_{H} U=0.01\left(\mathrm{~m} \mathrm{~s}^{-1}\right)
$$

After we estimated the daily mean sensible heat flux, we calculated the average value for a 3-day period, 5-day period, 10-day period, 20-day period and 30-day period from these daily mean values. We then calculated the root mean square error (RMSE) of the estimated sensible heat flux by the bulk transfer method for each averaging days period, using

$$
\mathrm{RMSE}=\sqrt{\frac{1}{N} \sum_{i=1}^{N}\left(x_{0}-x_{e}\right)^{2}}
$$

where $N$ is the number of data values, $x_{o}$ is the observed value of the daily mean sensible heat flux, and $x_{\varepsilon}$ is the value of the sensible heat flux estimated by the bulk transfer method.

\section{Estimation of the daily mean soil tempera-} ture by the method of Hirota et al. (1995)

The exchange speed, $C_{H} U$, for sensible heat flux is also an important parameter for estimating the soil temperature using a heat balance model combined with the bulk transfer method. Therefore, we also examined the accuracy of estimating the daily mean soil temperature by using the heat balance model without using wind speed data.

The daily mean soil temperature was estimated by the method of Hirota et al. (1995) using the three parameters of $C_{H} U$ (CASE 1, CASE 2 and CASE 3) mentioned above. The model is composed of a heat balance model for estimating daily mean soil temperature related to the Force-Restore Model (see Appendix). This model was verified with observed data. The resulting root mean square error of the estimated value was approximately $0.6^{\circ} \mathrm{C}$, when used with suitable values of $C_{H} U$ and surface moisture availability $\beta$ (see Appendix). In this analysis, we adopted the same meteorological data from May 19 to July 26, 1992 and the same parameters as in Hirota et al. (1995) except for $C_{H} U$.

According to Hirota et al. (1995), the average value of surface moisture availability $\beta$ over a period ranging from several days to several tens of days provides a good estimation of daily mean soil temperature. The surface moisture availability $\beta$ was taken as 0.56 from May 19 to June 20, 0.24 from June 21 to July 17 , and 0.56 from July 18 to July 26 (Hirota et al. 1995).

\section{RESULTS AND DISCUSSION}

Fig. 2 shows the relationship between the RMSE of estimated sensible heat flux for each case (CASE 1, CASE 2 and CASE 3) and the averaged number of days.

According to Fig. 2, the accuracy of the estimated sensible heat flux of CASE 1 is better than that of CASE 2 and CASE 3. CASE 3 gives the worst result of the three. The RMSE of daily mean values were as follows: In CASE 1 it was $10.5 \mathrm{~W} \mathrm{~m}^{-2}$, in CASE 2 it was $12.1 \mathrm{~W} \mathrm{~m}^{-2}$ and in CASE 3 it was $18.3 \mathrm{~W} \mathrm{~m}^{-2}$. These results are to 


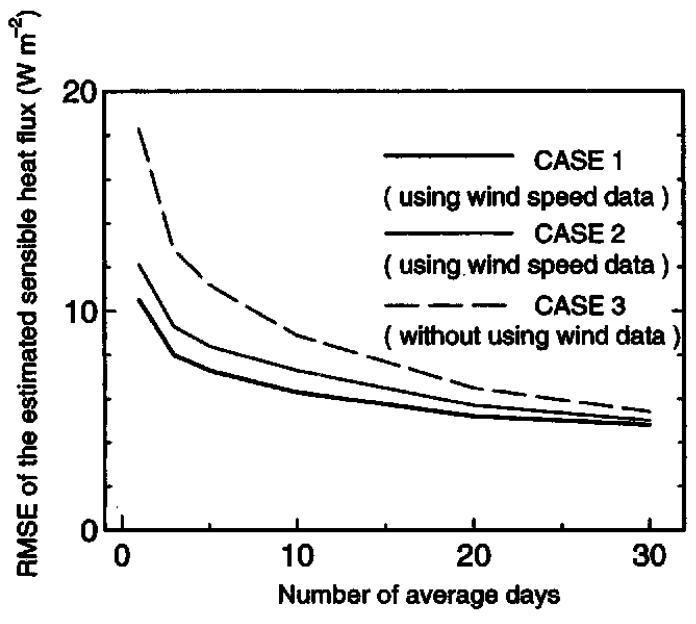

Fig. 2 Relationship between root mean square error (RMSE) for sensible heat flux estimated by the bulk transfer method using daily mean value and averaged number of days

be expected because in CASE $1 C_{H} U$ was parameterized based on the observed flux while in CASE $3 C_{H} U$ was treated as a constant value. The RMSE of the 3-day average in CASE 2 is almost equal to that of the daily mean value in CASE 1 . The RMSE of the 5-day average in CASE 3 is still $11.2 \mathrm{Wm}^{-2}$, which is larger than the RMSE of the daily mean value in CASE 1 . However, as the averaging period becomes longer, the difference of RMSE between three cases becomes smaller. For that of the 30-day average (monthly average), the RMSE of CASE 3 is almost equal to that of CASE 1 and CASE 2 at about $5 \mathrm{Wm}^{-2}$. This result shows that the accuracy of monthly sensible heat flux estimated without wind speed data is almost equivalent to that estimated with wind speed data. Thus, the estimated cumulative sensible heat flux agreed with the observed data even when $C_{H} U$ was treated as a constant value in CASE 3 (Fig. 3).

In this data analysis, the relationship between $U$ and $\Delta T$ yielded a poor correlation $\left(r^{2}=0.0296\right)$ as shown in Fig. 4 and the absolute value of $\Sigma$ $\left(C_{H} U\right)^{\prime}(\Delta T)^{\prime}$ is less than 4 percent of $n \times \overline{C_{H} U \Delta}$ $\bar{T}$. We considered that $\Sigma\left(C_{H} U\right)^{\prime}(\Delta T)^{\prime}$ is negligibly small and this is why the cumulative sensible

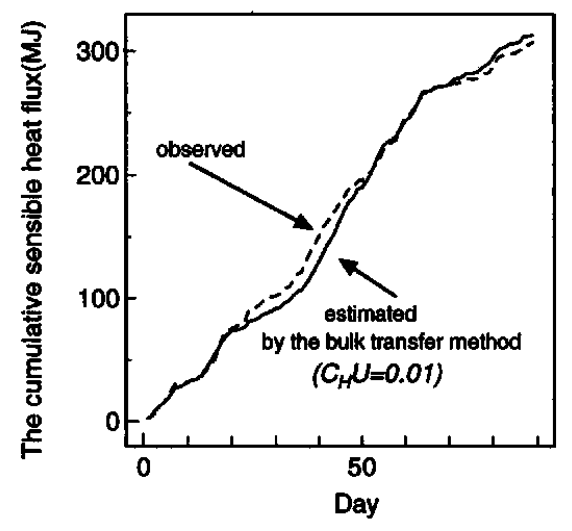

Fig. 3 Comparison of estimated and observed cumulative sensible heat flux Data from May 15 to July 26 and from July 29 to August 14 except August 12

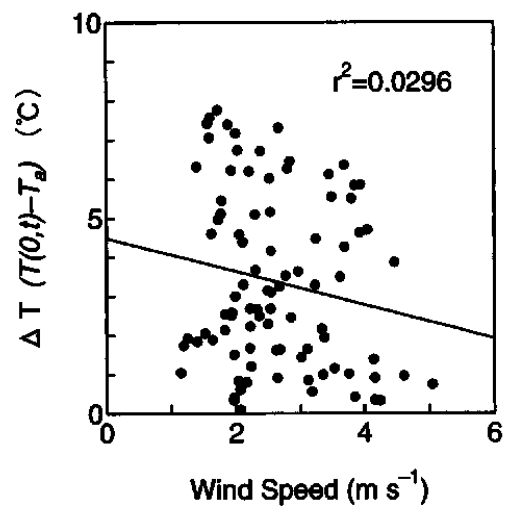

Fig. 4 Relationship between $\Delta T$ and $U$ at 0.5 m

heat could be estimated well even when $C_{H} U$ was treated as a constant value. Furthermore, $C_{H} U$ in CASE 3 was determined from only routine meteorological data without using observed flux data. This means that the cumulative sensible heat flux on bare soil can be estimated from the daily mean value of routine meteorological data without using wind speed and without calibration by using observed flux data

Fig. 5 shows the case of estimating the daily mean soil temperature. Although the estimation in CASE 3 could not quite catch up with the variations in observed values, as compared with the estimation in CASE 1, the RMSE for CASE 3 was almost equal to that for CASE 1. The RMSE for 


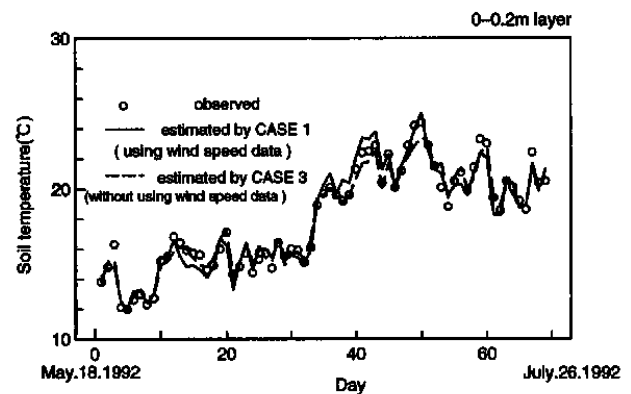

Fig. 5 Comparison of estimated and observed daily mean soil temperature

CASE 1 and CASE 3 were about $0.6^{\circ} \mathrm{C}$. This result indicates that even if wind speed data is not used, the model still provides a good estimation of the daily mean soil temperature. The soil temperature calculation was integrated using Eq. (14) (see Appendix) from an initial value. Both the soil temperature calculation and the cumulative sensible heat flux calculation are essentially the same, since this cumulative (integrated) value cancels out the error of each day's estimation. This is why daily mean soil temperature can be estimated accurately without wind speed just as cumulative sensible heat flux can be estimated well without wind speed. The method of Hirota et al. (1995) also can

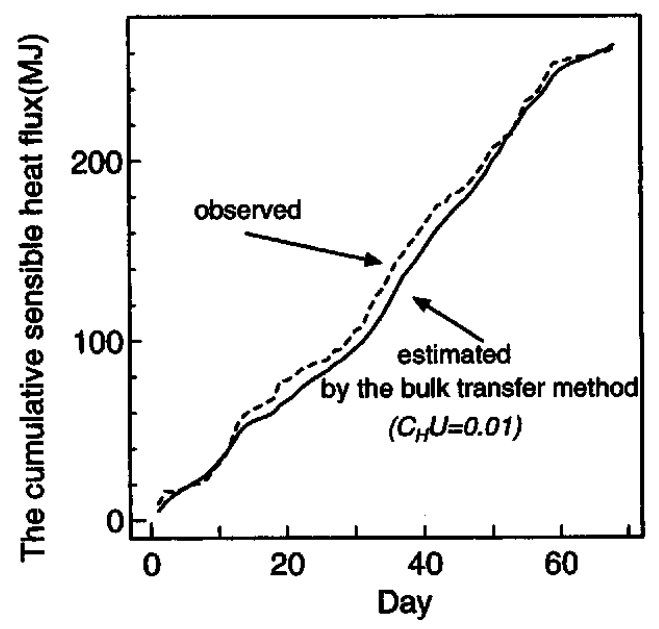

Fig. 6 Comparison of observed cumulative sensible heat flux with that estimated by the method of Hirota et al. (1995) Data from May 19 to July 26 estimate the sensible and latent heat fluxes. Fig. 6 shows the cumulative sensible heat flux estimated by the model without using wind speed data (CASE 3). This estimated result also agreed with the observed value, as it had in Fig. 3 .

\section{CONCLUSION}

Using theoretical and data analysis, we investigated the accuracy of estimating sensible heat flux and daily mean soil temperature for a bare soil using daily mean meteorological data without using wind speed data.

For the estimation of the cumulative sensible heat flux over several days or several tens of days, we showed that the exchange speed $C_{H} U$ can be parameterized without using flux observations and can be treated as a constant value. The monthly mean sensible heat flux estimated without using wind speed is almost equal to that estimated using the wind speed data. In conclusion, our research shows that the cumulative sensible heat flux over bare soil for long-term periods can be estimate using only routine meteorological data without wind speed. The daily mean soil temperature was also estimated well by the method of Hirota et al. (1995) without using wind speed data. It is considered that this approach is effective for the estimation of heat flux over long periods or for the estimation of daily mean soil temperature of bare soil by using routine meteorological data.

Recently, it has been recognized that long-term evaluations, such as seasonal or inter annual variations of the heat flux at the earth's surface are important in order to understand the climatic system (Yasunari and Koike, 1993; Betts et al. 1996). However, direct flux observation methods such as the eddy correlation method or the Bowen ratio method require costly equipment that is often difficult and expensive to maintain. Therefore it is not easy to provide continuous flux observation data for long-term periods for hydrology or climatology. The method proposed in this paper is effective for long-term estimations on a bare soil, because its accuracy is almost equivalent to that of using direct flux observations (the monthly mean 
value is estimated to within about $5 \mathrm{~W} \mathrm{~m}^{-2}$ ). This method is helpful where there is missing data for estimating the monthly mean flux. Therefore we consider that this method is also useful where we can obtain only operational meteorological data to estimate fluxes for long-term analysis such as climatic change. Moreover, even without wind speed data, we can estimate the cumulative sensible heat flux over several days or several tens of days as well as the daily mean soil temperature.

Although our investigation proved to be accurate for our conditions, it still requires testing under various surface and metrological conditions. Even if we do not have the various field flux observations data, the relationship between the exchange speed (wind speed) and the difference of ground surface temperature and air temperature can be investigated using operational meteorological data such as wind speed, air temperature, soil temperature. Future work with the method used in this study will involve analysis of the relationship between wind speed and the difference of ground surface temperature as well as verification with flux observation datasets.

APPENDIX:Estimation of daily mean soil temperature by the Force-Restore Model (Hirota et al., 1995; Hirota, 1999)

The Force-Restore Model for estimating daily mean soil temperature using daily mean or daily meteorological data, is expressed by

$$
\begin{aligned}
C 1(\delta) \frac{\partial T_{s}(\delta, t)}{\partial t}= & \frac{2}{c D_{a}} G(0, t)- \\
& \frac{2 \pi}{\tau_{y}}\left(T_{8}(\delta, t)-T_{y m}\right)
\end{aligned}
$$

where $T_{s}(\delta, t)$ is the average temperature $\left({ }^{\circ} \mathrm{C}\right)$ in a soil layer with a thickness of $\delta(\mathrm{m}), c$ is the volumetric heat capacity of the soil $\left(\mathrm{J} \mathrm{m}^{-3} \mathrm{k}^{-1}\right), D_{a}$ is the damping depth $(\mathrm{m}), G(0, t)$ is the soil heat flux at the surface $\left(\mathrm{W} \mathrm{m}^{-2}\right), T_{y m}$ is the annual mean soil temperature $\left({ }^{\circ} \mathrm{C}\right), \tau_{\text {, }}$ is the annual period ( 365 days $)$, and $C 1(\delta)=\left(1+2 \delta / D_{a}\right)$.

The Force-Restore Model was originally developed for a simple prediction of diurnal variation of ground surface temperature (e.g., Bhumarlkar, 1975;
Deardorff, 1978; Lin, 1980; Dickinson, 1988). Regarding the annual variation of daily mean value, we have shown that the Force-Restore Model not only accurately estimates ground surface temperature but also soil temperature in a layer up to approximately $50 \mathrm{~cm}$ thick for agricultural land (Hirota $e t$ al., 1995; Hirota, 1999).

Eq. (14) is usually used in combination with the following equations (15)-(19).

In the case of $\delta \rightarrow 0$

$$
\begin{aligned}
\frac{\partial T(0, \mathrm{t})}{\partial t}= & \frac{2}{c D_{a}} G(0, t)- \\
& \frac{2 \pi}{\tau_{y}}\left(T(0, t)-T_{y m}\right)
\end{aligned}
$$

where $T(0, t)$ is the ground surface temperature $\left({ }^{\circ} \mathrm{C}\right)$. The heat balance at the earth's surface is given by:

$$
\begin{aligned}
& G(0, t)=R_{n}-l E-H \\
& R_{n}=(1-a) R_{s}+\varepsilon\left(L_{d}-\sigma(273.15+T(0, t))^{4}\right)
\end{aligned}
$$

where $R_{n}$ is the net radiation $\left(\mathrm{W} \mathrm{m}^{-2}\right), R_{s}$ is the solar radiation $\left(\mathrm{W} \mathrm{m}^{-2}\right), L_{d}$ is the atmospheric longwave radiation $\left(\mathrm{W} \mathrm{m}^{-2}\right), l E$ is the latent heat flux $\left(\mathrm{W} \mathrm{m}^{-2}\right), H$ is the sensible heat flux $\left(\mathrm{W} \mathrm{m}^{-2}\right) . a$ is the soil albedo, $\varepsilon$ is the emissivity of the ground, and $\sigma$ is the Stefan-Boltzmann constant ( $\mathrm{W} \mathrm{m}^{-2}$ $\mathrm{K}^{-4}$ ) The latent heat flux $l E$ and the sensible heat flux $H$ are expressed by the following bulk formulas (Kondo, 1994):

$$
\begin{aligned}
& H=c_{p} \rho C_{H} U\left(T(0, t)-T_{a}\right) \\
& l E=l \rho \beta C_{H} U\left(q_{s a t}(T(0, t))-q_{a}\right)
\end{aligned}
$$

where $l$ is the heat of vaporization $\left(\mathrm{J} \mathrm{kg}^{-1}\right), \beta$ is the surface moisture availability, $C_{H}$ is the bulk transfer coefficient for sensible heat flux, $U$ is the wind speed $\left(\mathrm{m} \mathrm{s}^{-1}\right), C_{H} U$ is the exchange speed for sensible heat flux $\left(\mathrm{m} \mathrm{s}^{-1}\right), q_{a}$ is the specific humidity of the air $\left(\mathrm{kg} \mathrm{kg} \mathrm{k}^{-1}\right), q_{\mathrm{set}}(T(0, t))$ is the saturation value of the specific humidity at the ground surface temperature $\left(\mathrm{kg} \mathrm{kg}^{-1}\right), c_{p}$ is the specific heat of air $\left(\mathrm{J} \mathrm{kg}^{-1} \mathrm{~K}^{-1}\right), \rho$ is the air density $\left(\mathrm{kg} \mathrm{m}^{-3}\right)$, and $T_{a}$ is the air temperature $\left({ }^{\circ} \mathrm{C}\right)$.

ACKNOWLEDGEMENT: The authors thank Dr Toshio Koike for his thoughtful comments and encouragement. They appreciate Dr Charles Maule 
and Dr Raoul Granger for English revisions. They are also grateful to Mr. Yukiyoshi Iwata for his assistance in GPS measurement.

\section{REFERENCES}

Betts, A.K., Ball J.H., Beljaars, A.C.M., Miller, M.J. and Viterbo P.A. (1996): The land surface-atmosphere interaction: A review based on observational and global modeling perspectives, J. Geophys. Res., 101, pp. 7209-7225.

Bhumralkar, C.M. (1975) : Numerical experiment on the computation of ground surface temperature in an atmospheric circulation model, J. Appl Meteor., 14, pp. 1246-1258.

Brutsaert, W.H. (1982) : Evaporation into the Atmosphere, 299pp., Kluwer Academic Publishers.

Deardorff, J.W. (1978) : Efficient prediction of ground surface temperature and moisture inclusion of a layer of vegetation, J. Geophys. Res., 83, 1889-1903.

Dickinson, R.E. (1988) : The Force-Restore Model for surface temperature and its Generalization, J. Climate., 1, 1086-1097.

Fukumoto, M. and Hirota T. (1994) : The effect of surface soil moisture on a heat balance at a bare soil surface, J. Jpn Soc. Hydrol and Water Resour, 7, pp. 393-401 (in Japanese with English summary).

Fukumoto, M. (1999) : Study of evaporation from bare soil surfaces and surface soil moisture. Res. Bull. Hokkaido Natl Agric Exp Stn., 169, pp. 1586 (in Japanese with English summary).

Hanawa, K. (1993) : The problem of flux estimation by bulk transfer method from sea surface,
Kisyo Kenkyu Note, 180, pp. 31-50 (in Japanese). Hirota, T., Fukumoto, M., Shirooka, R. and Muramatsu, K. (1995) : Simple method of estimating daily mean soil temperature by using Force -Restore Model, J. Agr. Meteor., 51, pp. 269-277 (in Japanese with English abstract).

Hirota, T. and Fukumoto, M. (1996) : A discussion of ground surface temperature on a bare soil surface and an estimation of the daily mean value of sensible heat flux using routine meteorological data, J. Jpn. Soc. Hydrol and Water Resour., 9, pp. 395-403 (in Japanese with English summary).

Hirota, T. (1999) : Studies on evaluation of soil temperature, soil moisture and heat balance at the earth's surface for long periods under farmland and natural field conditions, Res. Bull. Hokkaido Natl. Agric. Exp. Stn., 169, 87-145 (in Japanese with English summary).

Kondo, J. (eds). (1994) : Meteorology of the water environment-Water and heat balance of the earth-, 337pp., ASAKURA Co. Ltd (in Japanese).

Lin, J.D. (1980) : On the Force-Restore Method for prediction of ground surface temperature, J. Geophys. Res., 85, 3251-3254.

Morton, F.I. (1983) : Operational estimates of areal evapotranspiration and their significance to the science and practice of hydrology, J. Hydrol, 66, pp. 1-76.

Yasunari, T. and Koike, T. (1993) : Global climate and hydrological circulation of Asian monsoon, Kagaku, 63., pp. 626-634 (in Japanese).

(Received: Oct. 4, 2000, Accepted: May 18, 2001) 